\section{Benedito Emílio Ribeiro Vanderlúcia da Silva Ponte}

Universidade Federal do Pará (UFPA)

\title{
Por uma história dos
} índios no Grão-Pará: estratégias, dinâmicas e protagonismos indígenas no contexto do Diretório Pombalino (1757-1798)

For a history of the Indians in the GrãoPará: indigenous strategies, dynamics and protagonisms in context of the Pombaline Directory (1757-7798)

\section{Resumo}

0 presente artigo analisa as múltiplas relações entre índios e brancos, que se desenvolveram dentro do universo colonial a partir da produção do chamado "processo civilizatório", previsto pelo Diretório Pombalino para o norte da América Portuguesa. O estudo centra-se no período entre 1757 e 1798, e enfatiza o Estado do Grão-Pará. Podemos bem precisar as resistências, alianças e conflitos que marcaram as sínteses daquela sociedade no contexto desta política que, ao inserir novos atores e segmentos sociais e criar novos espaços de sociabilidade, inaugurou uma nova ordem no tecido social na segunda metade do século XVIII.

Palavras-chave: História indígena; Grão-Pará; Diretório Pombalino; Relações étnico-sociais.

\section{Abstract}

This article analyses the multiple relations between Indians and whites, which developed within the colonial universe, from the production of the so-called "civilizational process", foreseen by the Pombaline Directory for the northern Portuguese America. The study focuses on the period between 1757 and 1798, and emphasizes the state of Crão-Pará. We can well specify the resistances, alliances and conflicts that marked the syntheses of that society in the context of this policy that, by inserting new actors and social segments and creating new spaces of sociability, inaugurated a new order in the social fabric in the second half of the eighteenth century.

Keywords: Indigenous history; GrãoPará; Pombaline Directory; Ethnic-social relations.

"Uma versão preliminar deste trabalho foi apresentada no Simpósio Temático "História Indígena", coordenado pelos professores André Pompeu e Rafael Santos, com o título A dinâmica da civilização pombalina: índios e brancos no contexto do diretório no Grão-Pará (1757-1798), do II Encontro de História Indígena e do Indigenismo na Amazônia, ocorrido em Belém (PA) entre os dias 5 e 7 de outubro de 2016, na Universidade Federal do Pará (UFPA). 

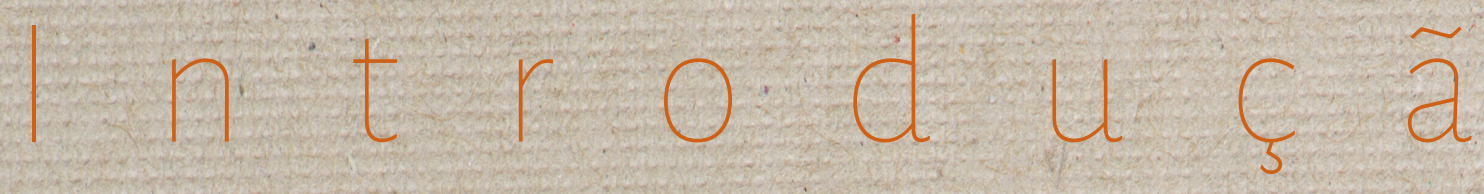

s políticas indigenistas, adotadas pela Metrópole lusitana para o espaço que hoje com- a análise da história deste período na Amazônia, tendo em vista a dinamicidade que estas oferecem para se en- preende a Amazônia,

caracterizam-se como medidas administrativas que procuravam legalizar o trato das populações indígenas, mas que tinham como objetivos implícitos, e igualmente intrínsecos, promover a consolidação portuguesa do domínio territorial, organizar as relações de poder e de trabalho, e também desenvolver os arranjos socioculturais. Elas contornaram todo o empreendimento colonial, tanto nesta região quanto no restante da América Portuguesa. Assim sendo, tais políticas podem ser encaradas como elementos expressivos para
Através dele podemos observar o complexo e delicado universo de relações ejogos de poder existentes no Estado do Grão-Pará e Maranhão na temporalidade em questão, onde os principais sujeitos - ordens religiosas, clérigos seculares, autoridades locais e metropolitanas, colonos/ moradores e ameríndios. Principais, demais aldeados e arredios - criavam suas teias de interesses no campo das relações interpessoais, para poderem exercer suas relações de dominação e subordinação no âmago daquele mosaico social emergente tender os processos históricos, gerados a partir da inserção desses projetos metropolitanos na realidade particularmentevivenciada pelos sujeitos naquela região, suscitando transformações em ambos - projetos e realidades.

Partindo deste ponto, assinalamos o processo histórico engendrado, no espaço amazônico, pela aplicação do Directorio que se deve observar nas Povoaçoens dos Indios do Pará, e Maranhã̃em quanto Sua Majestade naõ mandaro contrario (apud MOREIRA NETO, 1988, p. 165-206), ao longo da 
segunda metade do Setecentos, como indispensável para a apreensão histórica da Amazônia colonial. Através dele podemos observar o complexo e delicado universo de relações e jogos de poder existentes no Estado do Grão-Pará e Maranhão na temporalidade em questão, onde os principais sujeitos - ordens religiosas, clérigos seculares, autoridades locais e metropolitanas, colonos/moradores e ameríndios Principais, demais aldeados e arredios - criavam suas teias de interesses no campo das relações interpessoais, para poderem exercer suas relações de dominação e subordinação no âmago daquele mosaico social emergente.

Entendemos que essas múltiplas práticas sociopolíticas lançam as bases para se refletir sobre o locus amazônico nesse contexto, no qual as populações indígenas foram inseridas como agentes nos espaços coloniais, contribuindo para a tessitura de outra ordem de sociabilidades no Estado do Grão-Pará, nessa segunda metade dos Setecentos. De tal maneira, buscamos investigar as possibilidades imbricadas nas fontes que aludem a este período, no intuito de alcançar uma pers- pectiva diferente, voltada para uma história propriamente indígena, que nos revele as formas de atuação social, dos sujeitos ameríndios naquela nova realidade, suscitada pela política indigenista do Diretório dos Índios (17571798).

Para isto, nos propomos a analisar o texto referente ao Directorio e a documentação relativa ao período de vigência deste dispositivo existente no Arquivo Histórico Ultramarino (AHU). Após uma análise meticulosa destas fontes, e um intercruzamento dos dados obtidos com a historiografia produzida sobre o recorte temporal e temático selecionados, é possível perceber uma parte significativa da história deste período, a qual traz à tona um pequeno pariorama do campo relacional existente, envolvendo índiose não índios, no seio daquelá sociedade setecentista. Esta breve (re)construção histórica da conjuntura amazônica na segunda metade do século XVIII pôde ser realizada utilizando o método indiciário proposto pelo historiador Carlo Ginzburg.

Segundo Ginzburg (1989), as observações analíticas de pequenos sinais, 
de vestígios mínimos e de informações ocasionalmente negligenciáveis exiśtentes na documentação, permitem a compreensão de uma determinada realidade a partir de outro olhar sobre este passado, não experimentado anteriormente sem tal possibilidade metodológica. Através deste recurso, conseguimos preencher algumas lacunas ainda presentes na historiografia sobre o período arrolado; no entanto, outras ainda necessitam de investigações mais minuciosas e de quadros explicativos plausíveis, e existem ainda aquelas que, possivelmente, nunca conseguiremos vislumbrar (VEYNE, 2008).

Cabe-nos, ainda, esclarecer dois pontos referentes ao presente estudo. Em primeiro, a espacialidade: a Amazônia à qual nos referimos encontrava-se englobada, nos moldes da temporalidade analisada, no antigo Estado do Crão-Pará e Rio Negro'; porém, o foco espacial é nas paragens correspondentes ao Crão-Pará ${ }^{2}$. E em segundo, as

1"Isto corresponde hoje, com alguma aproximação, a grande parte dos Estados de Amazonas e Pará (excetuados os seus extremos norte e sul) e às porções leste de Roraima e sul do Amapá" (PORRO, 2007, p. 9).

2 Composto pelo continente do Pará, pela ilha de Marajó, pelo Cabo do Norte e pelos sertões dos principais rios da região (Tocantins, Xingu, Tapajós e Amazonas - principalmente o baixo e médio curso), é denominado de Capitania do Pará por José Monteiro de Noronha (2006), em seu Roteiro da Viagem da Cidade do Paráaté as Últimas Colônias do Sertão dá Província (1768). categorias utilizadas: branco enquadra-se como designativo comum aos europeus e/ou euro-brasileiros que habitavam no Grão-Pará, os quais compunham os mais variados segmentos daquela sociedade colonial; já índio/ ameríndio/indígena são termos historicamente construídos - sobretudo o primeiro - para definir genericamente aqueles habitantes nativos das Américas ${ }^{3}$, mas empregados aqui sem desconsiderar a pluralidade étnico-cultural destes povos.

\section{Diretório e discurso civilizatório nos trópicos amazônicos}

O Directorio que se deve observar nas Povoaçoens dos Indios do Pará, e Maranhaõ em quanto Sua Majestade naõ mandar o contrarió, instituído pelo alvará de 3 de maio de 1757 , é concebido como um

3 "[...] índio é um conceito construído no processo de conquista da América pelos europeus. Desinteressados pela diversidade cultural, imbuídos de forte preconceito para com o outro, o indivíduo de outras culturas, espanhóis, portugueses, franceses e anglo-saxões terminaram por denominar da mesma forma povos tão díspares quanto os tupinambás e os astecas. Atualmente, todavia, a palavra índio assumiu um significado mais complexo, pois os próprios povos que antes eram discriminados por esse termo hoje se identificam como tal, construindo sua identidade cultural a partir dele" (SILVA \& SILVA, 2009, p. 222). 
regimento eminentemente colonial, pois foi desenvolvido no âmago da réalidade existente no Crão-Pará e refletia as necessidades demandadas pelos colonos que o habitavam naquele contexto (COELHO, 2005; SOUZA JUNIOR, 2009; SAMPAIO, 2011). Assim, a conjuntura vivenciada naquele locus, a qual se intensificou em meados do Setecentos, desponta como fundamental para se compreender a construção das diretrizes desta legislação indigenista, que posteriormente será adotada e implantada pelo Estado português no norte da América Portuguesa 4 .

O ponto central da lei do Diretório dos Indios, conforme nos apontam Coelho (2005) e Souza Junior (2009), emergiu

4 Os principais pontos que perpassaram aquela conjuntura, e que são analisados pelos autores já citados - em maior ou menor grau -, foram: 1) a demarcação dos limites coloniais entre as Coroas ibéricas, engendrada pelo Tratado de Madri, assinado em 1750 , e a ocupação territorial; 2) os anseios pelo desenvolvimento econômico da colônia americana, sobretudo do Estado do Grão-Pará e Maranhão, devido à crise enfrentada pela Metrópole lusa neste contexto; 3) a autoridade hegemônica das ordens religiosas, principalmente a jesuítica, as quais possuíam um amplo domínio sobre as populações indígenas, força de trabalho basilar nesta região; 4) as querelas envolvendo o controle e a repartição da mão-de-obra indígena entre colonos, padres regulares e Metrópole. Estas questões, somadas a outras situações, influenciaram a visão de Francisco Xavier de Mendonça Furtado, então governador do Estado do Grão-Pará, e as medidas tomadas pelo Estado português para aquele espaço colonial, já que Mendonça Furtado informava constantemente os dirigentes metropolitanos, em Lisboa, sobre as condições experimentadas no norte da América' Portuguesa. com a aplicação da Lei de Liberdade dos Índios de 1755: tornou-se necessário repensar esta liberdade que foi, concedida aos indígenas, pois estes haviam abandonado os aldeamentos e provocado, desta maneira, certo colapso no fornecimento de mão-de- obra na região. Portanto, manter o controle sobre os ameríndios era imprescindível para efetivar as projeções coloniais - tanto da Metrópole quanto dos moradores do Grão-Pará. 'E para isso, reinseriu-se o regime tutelar como forma de efetivar essa autoridade sobre o indígena, suscitando uma mudança no aspecto da liberdade, de plena para tutelada.

Essa tutela justificou-se pela inaptidão dos indígenas que, por conta de sua rusticidade e' ignorância, não poderiam exercer plenamente seu autogoverno ${ }^{5}$. Logo, ela foi délegada aos agentes brancos da sociedade luso-brasileira estabelecida no Grão-Pará, os quais deveriam administrar esta massa trabalhadora indígena e também direcioná-la para um processo de amansamento e transformação, o qual se convencionou denominar

5 Cf. DIRECTORIO (1988, p. 166). 
de "civilizatório", em prol de um bem sociocultural e, igualmente, político-econômico. Deste modo, o Directorio aglutinava índios e brancos dentro de uma proposta progressista para o Grão-Pará, a qual previa um "processo civilizatório" direcionado aos indígenas, mas que englobava, também, os demais segmentos da sociedade local, em outras escalas de participação.

\section{Esse "processo civilizatório" estava} calcado em uma visão específica do índio, presente na mentalidade colonial, que se transformou a partir das pretensões do governo português e dos colonos, em meados do Setecentos, para aquelas populações no Grão-Pará, conforme já explicitadas. Das percepções predecessoras existentes ${ }^{7}$, são perceptíveis como alguns elemen-

6 Este "processo civilizatório" está em consenso com aquele elaborado por Norbert Elias, em seu livro O Processo Civilizador (1994).

7 No século XVI, havia duas possibilidades de se enxergar o índio: a) como ser humano, ainda selvagem, que deveria ser convertido, catequisado e civilizado; b) como ser inferior, animalizado, sem potencial para cristianizar-se, restandoIhe apenas a escravização e/ou dizimação (OLIVEIRA \& FREIRE, 2006). Essas imagens quinhentistas espelharam as formas de tratamento das populações indígenas, expressas nas legislações indigenistas coloniais, conforme analisado por Perrone-Moisés (1992). Assim, percebemos que a primeira imagem norteou o tipo de trato dado aos "índios mansos ou amigos", aliados dos portugueses; enquanto que a segunda foi direcionada aos índios inimigos, "gentios bravos" que não se submetiam ao julga português e que poderiam representar uma ameaça a estes, caso se associassem a outros desbravadores. tos foram elencados e coadunados para a construção da imagem do índio setecentista: um ser humano inferiorizado, devido a sua gentilidade e seu comportamento selvagem/animalesco, mas potencialmente capaz de transformar-se em um humano completo, civilizado. E para que o indígena atingisse esse estágio de desenvolvimento social e cultural, aparentemente, mais elevado, ele necessitava ser guiado por aquele que já o havia alcançado: neste caso, o europeu.

O entendimento da ideia de inferioridade atribuída ao indígena encontra-se espraiado em alguns pressupostos do pensamento europeu neste período, os quais são discutidos por Kheith Thomas (19,88) e Norbert Elias (1994). O primeiro observa como o comportamento transitava entre o humano e o animalesco, devido às alusões animais atribuídas à maioria dos impulsos corpóreos, sendo que quem apresentasse um comportamento animalizado, neste período de total afirmação da primazia do homem sobre o mundo natural, estaria passível a receber o mesmo tratamento dado aos animais. Já o segundo avalia os padrões comportamentais como reflexos exterio- 
res do íntimo humano, da psique do indivíduo, que se transpassavam através da carga simbólica do comportamento, o que revelava a essência da pessoa: se era polida ou rústica.

Isso corrobora para atingirmos a ótica do europeu sobre o "ser" indígena. Nesta perspectiva dada pelos autores, os indivíduos que não apresentassem as condutas minimamente toleradas pela sociedade, ou por seus segmentos hegemônicos, seriam desumanizados e inferiorizados, pois intimamente eram bárbaros e bestiais; justificando a forma de relacionamento entre estes seres e os "verdadeiros" homens: os primeiros deveriam se sujeitar à vontade dos segundos. Assim, o discurso da ignorância, da rusticidade e incivilidade indígena estava inserido numa lógica de percepção cultural, a qual confirmava a dominação daqueles seres humanos. No contexto do Directorio, essa dominação dar-se-ia através da consolidação da presença branca naquelas povoações habitadas pelos indígenas, para o auxílio em seu processo de civilização.

De tal modo, este processo almejava reordenar as condútas sociais dos indivíduos, principalmente dos indígenas, a fim de transformar aquela sociedade colonial setecentista, visando homogeneizá-la de acordo com os parâmetros europeus de civilização. Esta tentativa foi impossibilitada anteriormente, devido à presença latente de práticas comportamentais indígenas, as quais se configuravam como baluartes de ignorância e barbárie naquela realidade social. Para contorná-la, buscou-se eliminar estes hábitos rústicos através de um refinamento daquelas camadas sociais compostas pelos ameríndios; e igualmente daquelas compostas por luso-brasileiros, pois haviam assimilado certos hábitos de procedência indígena (SAMPAIO, 2011). Percebe-se como essa práxis social do comportamento humano deveria ser um condicionante uniformizador para um direcionamento único da sociedade: de uma forma organizacional mais simples e "primitiva" - a indígena - para um caráter mais desenvolvido e complexo, uma sociedade nova e modernizadaao exemplo europeu.

Partindo desta argumentação, percebemos como as condutas "aceitáveis" foram sendo construídas no texto do 
Diretório e englobavam, reiteramos, os vários segmentos sociais - tanto de índios quanto de brancos - naquele território colonial. Por exemplo, à diretor, o principal encarregado pela civilização dos indígenas aldeados, era recomendado que fosse "dotado de bons costumes, zelo, prudencia, verdade, ciencia da lingua, e de todos os mais requisitos necessarios para poder dirigir com acerto os referidos Indios" (DIRECTORIO, 1988, p. 166). Tal padrão de postura, todavia, não foi somente encaminhado à figura dos diretores.

Também foi aconselhado que os demais representantes brancos nas povoações apresentassem e/ou desenvolvessem certas aptidões para a realização de suas respectivas funções, uma vez que estes mediavam e interviam na vida cotidiana dos índios àldeados. Fica explícito, portanto, que tais recomendações régias tinham por função a constituição de um modelo social das camadas brancas, sobretudo dos dirigentes, existentes nas vilas e lugares no Grão-Pará. Isto visava que os indígenas copiassem os exemplos de civilidade dados pelo branco, por meio de uma pedagogia de aprendizagem social' (ELIAS, 1994).
Conjuntamente a esta pedagogia do exemplo, foram organizados condicionantes para reformular os costumes indígenas e, dessa forma, fazê-los adentrar na vida civilizada. Alguns destes foram: o uso da língua portuguesa, o ensino para as crianças ameríndias, a concessão honorífica de encargos administrativos, o emprego de sobrenomes de estirpe lusitana, a construção e organização das casas ao estilo europeu, a utilização de vestimentas conforme o "status" ocupado, o incentivo aos casamentos mistos, o trabalho agroextrativista e o comércio etc. (DIRECTORIO, 1988, p. 168-202). A aplicação de tais mecanismos reproduziria o comportamento civilizado entre os índios aldeados, proporcionando-Ihes o aprendizado deste e a sua internalização, através da repetição cotidiana.

Estes elementos tutelares previam o exercício de um controle social sobre o indígena ${ }^{8}$, enquanto seus costumes

8 Este controle, desempenhado sobremaneira pelo diretor, nas povoações, se dava através de mecanismos referentes às instâncias das relações macro e micropolíticas, com o desígnio de disciplinar os corpos-tanto de brancos quanto de índios, estes principalmente-, aumentando sua utilidade, tanto para a povoação quanto para o Estado português, e desenvolvendo as formas de subordinação às quais estes contingentes docilizados estariam sujeitos (FOUCAULT, 1987). 
eram reorganizados, que se desdobraria em um autocontrole por parte destes, a posteriori. Este seria erigido através da observância dos hábitos e da autoconsciência refinada adquiridos ao longo do "processo civilizatório" pelos indígenas (ELIAS, 1993). Percebemos, então, como estes elementos tinham por função primária a quebra cultural das populações ameríndias, o apagamento de seu passado tribal e a perda de sua identidade étnica. Logo, estes grupos aldeados poderiam construir outras identidades, mais próximas do padrão civilizado europeu, cuja finalidade era fazê-los "branquearem-se" para que se unissem ao restante da sociedade lusitana no Grão-Pará: eis o discurso assimilacionista?.

Neste sentido, entendemos o Diretório dos Índios como uma política administrativa, erigida na Colônia e adotada pela Metrópole, que previa um novo modo de colonização para o norte da América Portuguesa, o qual se inseriu numa perspectiva mercantilista e numa lógica europeia de racionalidade e modernização. Visto como

9 Almeida (2000) ressalta esta política de assimilação em sua análise sobre o Directorio. inovador, ao trazer uma iniciativa laica de intervenção e integração para os ameríndios que viviam no Grão-Pará, este instrumento foi verdadeiramente letal ao modus vivendis daquelas populações, muitas das quais foram destribalizadas e eventualmente "incorporadas" na sociedade local $^{10}$. No entanto, veremos que isto não significou a desestruturação do sujeito indígena - o seu etnocídio - apenas emergenciou metamorfoses étnicas e novas formas relacionais para garantir a sua sobrevivência neste panorama inusitado (ALMEIDA, 2000; MONTEIRO, 2001).

\section{Estratégias e dinâmica sociocultural no Grão-Pará pombalino}

O Diretório dos Índios foi uma política indigenista virtualmente danosa às populações ameríndias no vale amazônico, em meadós do século XVIII.

10 Moreira Neto (1988) é enfático ao apontar este processo. Entretanto, não concordamos totalmente com a visão pessimista que ele constrói ao longo de sua obra, principalmente com a ideia de total destruição étnica dos grupos indígenas aldeados, tanto durante as Missões quanto no período do Directorio. 
Entretanto, é inegável afirmar que ele inaugurou uma ordem social diferenciada no Grão-Pará, uma vez que os atores indígenas foram imbuídos de outra lógica de ação, relacionada à sua nova condição gerada por este dispositivo legal (COELHO, 2005). Face este novo "status" jurídico e papel social, os ameríndios tomaram seus múltiplos posicionamentos e produziram uma clivagem, deste modo, no interior das intricadas hierarquias existentes entre dominados

Face este novo "status" jurídico e papel social, os ameríndios tomaram seus múltiplos posicionamentos e produziram uma clivagem, deste modo, no interior das intricadas hierarquias existentes entre dominados e dominadores, índios e brancos, naquele tecido social. Vale ressaltar que os ameríndios, perante esta nova ótica a qual foram circunscritos, trataram de criar estratégias para se salvaguardarem, bem como os seus respectivos grupos. os segmentos sociais sobrepujados produzem nas instâncias cotidianas da vida. A finalidade disto está em metaforizar a ordem determinada pelos discursos e transformá-la para ganhar outra tônica e funcionar segundo os anseios e interesses destes grupos. No caso do período de vigência do Directorio (COELHO, 2005; SOUZA JÚNIOR, 2009; SAMPAIO, 2011), estas estratégias apontam para as necessidades que os índios tinham em modificar a ótica das relações sócio-políticas e das representações socioculturais, buscando burlar as projeções assimilacionistas naqueles espaços, por excelência, de aglutinação étnica: as povoações indígenas $^{11}$.

11 Sobre estas configurações étnicas nas vilas e lugares no Grão-Pará, ver Sampaio (2011) e Porro (1992; 2007). 
Observa-se que, ao longo do processo colonial, muitas das populações indígenas foram remanejadas - ou descidas para locais distantes de seus respectivos territórios tradicionais e/ou de suas habituais áreas de circulação. Isso deveria ter provocado um enfraquecimento nas respectivas reproduções culturais e identitárias destes agrupamentos, as quais estão intrinsecamente relacionadas ao território e à carga simbólica a ele atribuída. Em meio a isto, contudo, emergiram métodos de reorganização social, assentados em processos de territorialização e conectados a uma série de estratégias (OLIVEIRA, 2004), que permitiram a salvaguarda de muitos elementos de ordem cosmológica e a manutenção, portanto, de seus sistemas socioculturais, reelaborados em perspectivas diferenciadoras. Essa manutenção tornou-se possível através da utilização, por parte dos ameríndios, dos preceitos estabelecidos pelo Directorio, apropriados e ressignificados por eles a fim de, dinamizar seus elementos identitários e culturais.

Circunscrito neste pensamento acerca da atuação dos ameríndios no Grão-Pará de meados do Setecentos, destacamos algumas medidas estratégicas utilizadas - real ou possivelmente - por estes sujeitos, a saber: a) descimentos; b) pedidos para concessão de cargos e patentes; c) denúncias; d) reafirmações de liberdade. Essas estratégias permitem-nos visualizar os protagonismos indígenas que se mascaram ora em insubordinações, conflitos e fugas, ora em aparentes alianças, influências e submissões. Foram estas resistências, explícitas e implícitas, desenvolvidas nos meandros das relações interpessoais, nas dissidên- 
cias entre segmentos sociais e nos matizes da vida cotidiana, que propiciaram e caracterizaram as composições específicas que foram produzidas ao longo deste período.

\section{Descimentos}

Encaramos os descimentos como uma estratégia adotada pelos indígenas, tendo em vista os benefícios que poderiam acarretar àquelas populações. Tais deslocamentos circunscreviam-se no cerne das políticas que estes sujeitos desenvolveram ao longo do processo de contato e negociação com o outro, neste caso o europeu. A sujeição ao descimento derivava, logo, dos interesses e das conveniências - da coletividade, de um determinado segmento e/ou de alguns indivíduos - sobre este empreendimento (COELHO, 2005; ROCHA; 2009).

Por exemplo, em um ofício, datado de 5 de novembro de 1760 , no qual está registrada uma série de descimentos. Entre eles, elencamos o seguinte:

Para a Villa de Sintra veio hum Mucambo, que constava de 62 pessoas, de ambos os sexos, descidos por hum Indio a quem mandei passar Patente de Principal em premio da sua fidelidade, e promessa de fazer maior descimento, e tambem o vesti a minha custa (AHU, Pará [avulsos], cx. 47, doc 4344)

Conforme ofragmento destacado acima, a patente de Principal foi concedida para aquele índio por duas razões: por realizar o descimento e por se comprometer a fazer outros, a fim de adensar aquela povoação. Nesse sentido, podemos observar que se firmava uma aliança entre índio e branco quando o primeiro demonstrava seu valor e sua lealdade para com o segundo, a qual era provada através do empreendimento ou do auxílio no descimento - bem como em outros assuntos relativos à consolidação do projeto colonial. Após isto, o indígena benevolente, que demonstrasse sua "fidelidade", era recompensado: poderia tornar-se principal, adquirir vestimentas e/ou ferramentas, entre outros. Isto o aproximava do europeu e permitia ao índio inserir-se naquela sociedade local (PRIORE, 2016).

\section{Pedidos para concessão de cargos e patentes}

Os pedidos de concessão de cargos e

12 Manuel Bernardo de Melo e Castro [Ofício apresentado para Francisco Xavier de Mendonça Furtado, em 5/11/1760]. 
patentes, que alguns índios faziam ao Rei, podem ser enquadrados como medidas estratégicas destes sujeitos. Concluímos isto uma vez que os indígenas souberam se apropriar das prerrogativas presentes no estatuto do Directorio, para contrair e/ou consolidar representatividade e poder perante as autoridades, os moradores e os próprios índios. Segundo Coelho (2005, p. 209), "as alterações ocorridas na base do poder das chefias indígenas são indicativas do quanto as sociedades indígenas - sempre que possivel-submeteram a uma agenda política própria, sua relação com o colonizador". Os documentos analisados, por conseguinte, corroboram com a ideia de construção de uma elite correspondente das lideranças indígenas, representadas pelos Principais e demais oficiais índios nas suas vilas e lugares. Estas elites também englobavam as respectivas famílias das lideranças, as quais compartilhavam igualmente as honras e prestígios circunscritos pelas posições que aqueles desempenhavam.

A constituição dessás elites indígenas apresentava uma finalidade pré-determinada naquele contexto colonial: erigir uma base subalterna de.poder entre os ameríndios, para quie os setores de ascendência lusitana exercessem um controle mais direcionado sobre aquelas populações. Então, as elites indígenas deveriam ser entrepostos políticos, por desígnio, entre os dominadores brancos e as comunidades ameríndias, que eram subordinadas àquelas elites. Mas, como apontado anteriormente, tais elites souberam se utilizar daquele mínimo poder que lhes foi conferido, para consolidar uma base sólida de autoridade ante a sociedade local.

Por exemplo; os pedidos de patente por parte dos filhos dos Principais denotam uma necessidade existente com relação à estabilização e reconhecimento do poder e do status das famílias que compunham aquelas elites. Isso é demonstrado nos requerimentos, que apontam a legitimação daqueles novos dirigentes indígenas através da memória das descendências de chefias anteriores. Com isto, assentavam a necessidade de reconhecimento nos postos e, portanto, promoviam o fortalecimento de suas atuais lideranças (COELHO, 2005; ROCHA, 2009). Destarte, os episódios elencados ajudam a trazer à tona as intrincadas formas como se organizaram essas elites indígenas no Grão-Pará. 
No caso de Cipriano Inácio de Mendonça, Isidoro António, Amaro Pereira da Silva e José da Costa de Sousa, estes índios - ou mamelucos, pois o documento não faz referência quanto a esta definição - requereram patentes com devido soldo por não poderem viver com a dignidade correspondente ao seu status social, enquanto filhos dos Principais de suas respectivas povoações (AHU, Pará [avulsos], cx. 57, doc. $5143)^{13}$. No caso de Silvestre Francisco de Mendonça Furtado, o mesmo fez alusão ao serviço prestado por seu pai, como Principal da vila de Porto de Mós, e demandou que Ihe fosse dada a patente de sargento-mor, para que ele prosseguisse em seu serviço com o mesmo empenho que o seu pai, continuando assim o seu "legado" (AHU, Pará [avulsos], cx. 60, doc. 5370) ${ }^{14}$.

Também temos o episódio envolvendo o índio Jerónimo António Rodrigues. No tocante a este sujeito, a documentação deixa claro que o mesmo era um "índio comum"15, que não nascera entre

13 Cipriano Inácio de Mendonça, Isidoro António, Amaro Pereira da Silva e José da Costa de Sousa [Requerimento apresentado para o rei D. José I, em 4/7/1764].

14 Silvestre Francisco de Mendonça Furtado [Requerimento apresentado para o rei D. José I, em 17/1/1767].

15 Entende-se por "índio comum", nessa conjectura, aqueles aldeados que não faziam parte das elites ameríndias locais, podendo ser enquadrados na condição de subalternos a estas. os membros da elite de sua povoação, mas que, ao provar seu valor e o mérito de possuir a patente de Principal, conseguira fazer a Coroa confiar-lhe tal incumbência, a qual detinha suas regalias (AHU, Pará [avulsos], cx. 52, doc. 4766$)^{16}$. Este caso descortina, por exemplo, a possibilidade de ascensão de indígenas na hierarquia social, e seu eventual reconhecimento nas sobreditas funções, evidenciando que a situação das elites estava totalmente cristalizada em torno de alguns indivíduos.

Outro episódio, que não se enquadra nesta categoria, mas é muito interessante para esta análise diz respeito ao indio Felipe de Santiago Monteiro, alferes da vila de Monforte. O documento mostra o pedido feito pelo governador do Grão-Pará, João Pereira Caldas, para que este indígena se tornasse diretor da dita vila, na ilha de Marajó. João Pereira Caldas recomendou que fosse lhe dado este cargo, pois o mesmo índio possuía as competências e aptidões necessárias para o exercício de tal incumbência (AHU, Pará [avulsos], CX. 87, doc. 7102) ${ }^{17}$. No entanto, a documen-

16 Francisco Xavier de Mendonça Furtado [Aviso apresentado para Alexandre Metelo de Sousa e Meneses, em 6/4/1762].

17 João Pereira Caldas [Ofício (minuta) apresentado para Martinho de Melo e Castro, em 1780]. 
tação não infere se ele conseguiu tal encargo. O evento deixa claro, portanto, as formas de articulação que os indígenas - sobremaneira aquelas èlites -, desenvolveram com algumas autoridades. Isso margeia as possibilidades de relacionamento entre aqueles sujeitos, e as redes de trocas e interesses que foram construídas no âmbito sócio-político, entre índios e brancos.

\section{Denúncias}

As harmoniosas sociabilidades que aparentemente se desenvolveram entre índios e brancos, no Grão-Pará, foram abaladas por inúmeras tensões irrompidas entre estes segmentos sociais, em meados dos Setecentos. 0 Diretório dos Índios, com seu programa de "integralização" e de "aceitação" dos indígenas no tecido social, não conseguiu aplacar a imagem de inferioridade que muitos moradores no Grão-Pará ainda possuíam com relação àqueles ameríndios, até mesmo autoridades, como diretores, párocos e governadores. Isso provocava epi- sódios de depreciação e desrespeito para com os novos "vassalos" do Rei, gerando denúncias sobre estes casos.

Em certo documento, os ameríndios do Grão-Pará pedem aceitação nos quadros da Ordem Terceira da Penitência, pois "se achao civilizados, e estabelecidos com cadebaes, e boms procedimentos" e, portanto, eram aptos para o ingresso nesta confraria. Entretanto, não eram admitidos na dita ordem "por serem descendentes de indios" (AHU, Pará [avulsos], cx. 45 , doc. 4082) ${ }^{18}$. Percebemos o posicionamento dos índios, que perante tal "injustiça", procuraram seus "direitos" e denunciaram nas instâncias administrativas aquela falta cometida. Em documento posterior, atestamos a punição dada ao padre responsabilizado pela recusa, sendo mandado regressar para Portugal. A denúncia revelou exatamente esses resquícios de imagens da mácula indígena que ainda faziam-se presentes no Grão-Pará, impossibilitando o reconhecimento da estima destes sujeitos sociais, os quais foram tratados de remediar pelo reforço dos dispositivos de "integração"

18 Índios e índias mamelucas do Estado do Pará [Requerimento apresentado para o rei D. Josél, em 2/6/1759]. 
do Directorio (AHU, Pará [avulsos], cx. 50, doc. 4606$)^{19}$.

\section{Reafirmações de liberdade}

As muitas animosidades que perpassam este período contribuíram para aumentar as insatisfações entre os indígenas do Estado do Crão-Pará. Elas suscitaram deserções e fugas para as matas do interior, provocando ruína e colapso nas povoações e, consequentemente, no Estado. Para aqueles que permaneciam nas povoações, a resistência ocorreu de forma diferenciada. Por exemplo, alguns indígenas utilizaram um discurso de reafirmação de liberdade, a partir de 1779 , rememorando o que foi instituído pela lei de 1755. Isso visava à garantia de "direitos", daquele momento em diante - possivelmente por conta das mudanças na gestão do império português, com a saída de Pombal em 1777, contexto que ficou conhecido como Viradeira.

Dentre os muitos casos observados na

19. Manuel Bernardo de Melo e Castro [Ofício apresentado para Francisco Xavier de Mendonça Furtado, em 2/10/1761]. documentação, elencamos um pedido de provisão feito por parte de um índio (ou mameluco). No documento, ele demanda que the fosse outorgado liberdade, enquanto direito assegurado pela Lei de 6 de junho de 1755 . Todavia, tal direito não podia ser-totalmente cumprido...

[...] pela sugeiçaõ, em que se achaõ os Indios Aldeados, naõ podendo sahir das mesmas Povoaçoes para outra qualquer parte onde lhe convier, e melhor conta The fizer, sem que seja por meio de fuga; e porque isto o offende naõ so o Direito natural, e Divino, senaõ taõbem as Leys de V. Mag.: motivo porque pertende, que, em virtude dellas se the mande passar Provizaõ para uzar da sua Liberdade como bem Ihe parecer, e sem que se the possa oppôr embarasso algum [...] (AHU, Pará [avulsos], cx. 96, doc. 7606) ${ }^{20}$.

Estas tramas nos revelam como os ameríndios afrontaram os ditames europeus, resistindo de, no mínimo, duas maneiras. A primeira, mais direta e incisiva: ao indagarem seus possíveis e/ou aparentes "direitos" nas instâncias administrativas, revelando seus conflitos com os colonos, as autoridades e, até mesmo, outros indígenas; ao fugirem para suas antigas

20 Jorge Francisco de Brito [Requerimento apresentado à rainha D. Maria I, em 23/11/1786]. 
terras; ao refugiarem-se nas matas e constituírem mocambos, reedificando outras possibilidades de convívio e sociabilidade. A segunda, disfarçadamente, configurando uma guerra silenciosa nos declives da banalidade cotidiana, que fazia passar despercebida a resistência indígena para com o elemento europeu e sua cultura civilizadora e envolvente. Isto pode ser exemplificado no seguinte fragmento do artigo de Agenor Sarraf Pacheco (2010, p. 90):

Nas artimanhas desenhadas para burlar controles e intolerâncias, nações indígenas e africanas refizeram espaços do sagrado, inseriram outros repertórios e oráculos de matrizes culturais diversas, alguns para enlaçar empréstimos e influências recíprocas, outros para usar a arma dominante e não se deixar encapsular.

Neste trecho, o autor examina as formas pelas quais os grupos, que tiveram seus sistemas culturais interpretados erroneamente pela mentalidade europeia - e, portanto, foram perseguidos e combatidos pela mesma -, buscaram proteger certos traços que eram característicos de suas identidades. Assim, eles reestruturaram suas culturas seguindo outros caracteres, os quais não impediam a identificação dos valores simbólicos da mesma, utilizando-se muitas das vezes de elementos relacionados à es-, trutura cultural dominante como forma de mostrar uma aparente aceitação e assimilação. Entretanto, no âmago das acepções desses grupos "marginalizados", os significados da mesma eram subvertidos e afinados com o sistema cosmológico destes.

Como é possível observar no escrutínio das fontes e da bibliografia atinente ao tema, o Diretório dos Índios e seu "processo civilizatório" não teve o sucesśo desejado ao tentar europeizar o indígena, suplantando sua matriz étnico-cultural. Ele, todavia, auxiliou na demarcação dos subsídios identitários dos grupos ameríndios - aldeados ou não - além de promover simbioses mais acentuadas entre certos elementos culturais indígenas e portugueses, construindo outras dimensões de cultura naquela região. Esses vários intercâmbios existentes entre ámbos, potencializados no Grão-Pará durante a vigência do Directorio, são observados desde o início da colonização da América Portuguesa, em idos do século XVI. 
Ressaltamos, dessa forma, a importância que essas interações, expressas em uma relação de mútua influência entre tais sujeitos, possuíam no cerne das representações simbólicas daquela sociedade, ao evidenciar, também, a penetração da cultura ameríndia na sociedade colonial21. Dessa forma, muitos elementos foram sendo incorporados de ambos os lados, denotando a criação de uma intercambialidade entre as culturas, nos trópicos da América Portuguesa. No entanto, entrar no mérito dessas relações de similitudes aparentes não denota falar sobre seus valores simbólicos no cerne de cada cultura. As semelhanças culturais, advertimos, terminam na exterioridade de suas

21 Sampaio (2011, p. 127) ratifica esta questão nos trópicos amazônicos. representações cosmológicas, devido às redes de significados que cada elemento irá possuir dentro, de um determinado sistema cultural.

Destarte, conseguimos observar, através deste balanço, como os indígenas introduziram a si próprios naquele empreendimento colonial, que havia sido delineado para o norte da América Portuguesa através da política pombalina do Diretório. Percebemos comoesses grupos "marginalizados" não desaparecem por completo, não foram verdadeiramente assimilados pelo tecido social, como pretendia o Directorio. Houve, contudo, uma dialética entre o discurso dessa política indigenista e as articulações concebidas pelas práticas socioculturais, entre os indígenas e os europeus. Isto produziu negocia- 
ções invisibilizadas ${ }^{22}$ entre as subjetividades ameríndias, as quais tinham por propósito a delimitação identitária daqueles grupos em seus arranjos e/ ou rearranjos culturais, naquele período e a posteriori, corroborando com a análise de Cristina Pompa (2008), que investigou o mesmo processo dialético entre as populações indígenas do Nordeste.

Ao investigar minuciosamente a documentação do Arquivo Histórico Ultramarino, procuramos notar a presença indígena neste contexto de meados do Setecentos. Percebemos, porém, uma quase completa invisibilidade desses sujeitos como protagonistas. Nessa perspectiva, conseguimos destacar apenas alguns casos "isolados"

22 Determinamos de "negociações invisibilizadas" as formas de organização dos caracteres culturais entre os vários grupos indígenas que estiveram em contato durante 0 período pombalino para construir os elementos simbólicos de diferenciação étnica, os quais são próprios desses ameríndios e acabam não sendo percebidos pelos segmentos não indígenas da sociedade local setecentista, e consequentemente não se encontram expressos na documentação, sobretudo de cunho oficial. No entanto, sabe-se que houvera essa espécie de negociação identitária ao se fazer o exercício analítico da composição cultural das sociedades ameríndias da atualidade, que reivindicaram, a partir da década de 1970, o seu reconhecimento jurídico enquanto povos originários do território brasileiro, revelando que o sentimento de identidade não havia sido destruído no decurso da história, mas que precisou ser silenciado ao longo do tempo para garantir a sobrevivência dessas populações em virtude das formas de repressão relacionadas a este viés, perpetradas, primeiramente, pela gerência metropolitana e, após a Independência, pelo Estado Nacional Brasileiro que então se formava. nestas fontes oficiais, com os quais pudemos observar e refletir sobre a participação indígena ao longo deste processo histórico. Entretanto, os eventos analisados, visivelmente desconexos e fragilmente documentados, apresentam, nas entrelinhas dos discursos, os indícios para a observação das vozes ameríndias; vozes estas que concretamente não foram silenciadas por completo no decurso histórico. Tal percepção ajuda no entendimento dos meandros condizentes àquela circunstância histórica, os quais dão margem à construção do protagonismo experimentado por aqueles ameríndios no Grão-Pará.

\section{Considerações finais}

\section{O Directorio é enfático ao estabelecer,} ao longo de seus dispositivos, que o diretor - o agente branco/europeu era a figura central nesta política indigenista, assim como era o religioso na época das Missões. Os ameríndios possuíam sua relevância naquelas políticas, mas foram relegados à colocação de agentes inertes ou ainda de sim- 
plórios objetos, com os quais o sujeito europeu iria efetivar o projeto colonial. No entanto, entre os discursos produzidos e as práticas realizadas, uma gama de fatores encetou-se e remodelou os ditames da lei. Isso conferiu uma tônica diferente para aquela realidade, em virtude das transformações engendradas quando os vários sujeitos entraram em cena; no palco deste processo histórico.

Assim, esta legislação mostra-se importante para a compreensão dos moldes sociais e seus parâmetros organizacionais, nas esferas de vida apreendidas para o período: coletiva, individual e cotidiana. O Diretório dos Índios trouxe ressignificações espaciais e novos dispositivos socioculturais, que modificaram tanto a vida dos ameríndios quanto dos demais agentes coloniais. Isso pode ser avaliado como um dos vários desdobramentos que a inclusão do componente indígena proporcionou nos trâmites socioculturais daquele período. Os índios, quando inseridos numa realidade diferente, trataram de arquitetar estratégias para que determinados elementos que caracterizavam suas identidades não fossem perdidos e/ou abandonados durante o "processo de civilização", solidificando certas práticas de seus antepassados e introduzindo outras, através de combinações entre a sua cultura e a portuguesa.

Grosso modo, o Diretório dos Índios engendrou uma série de tramas, construídas por índios e brancos, ao longo da segunda metade dos Setecentos. Elas foram marcadas pelos vários meios relacionais, que ambos experimentaram no decorrer do convívio social: as resistências indígenas, os conflitos velados entre os segmentos sociais - tanto entre índios e brancos, como entre os próprios indígenas em posições hierárquicas diferentes - as alianças mascaradas de segundas intenções, as subversões culturais que os ameríndios criaram para salvaguardar seu sentimento de identidade étnica etc. Em outras pálavras, conseguimos visualizar esse diálogo fluído e friccionado do contato interétnico. Ele nos possibilita conceber uma história diferenciada, a qual caracteriza os indígenas como verdadeiros protagonistas deste processo histórico na Amazônia. 


\section{Referências}

\section{Fontes primárias manuscritas:}

Arquivo Histórico Ultramarino (AHU). Acervo do Laboratório de História - Universidade Federal do Pará/Campus de Bragança.

AHU (Pará), cx. 45, doc 4082.

AHU (Pará), cx. 47, doc. 4344.

AHU (Pará), cx. 50, doc. 4606.

AHU (Pará), cx. 52, doc. 4766.

AHU (Pará), cx.57, doc. 5143.

AHU (Pará), cx. 60, doc. 5310.

AHU (Pará), cx. 87, doc. 7102.

AHU (Pará), cx.96, doc. 7606.

\section{Bibliografia citada e consultada:}

ALMEIDA, Maria Regina Celestino de. Os índios aldeados no Rio de Janeiro colonial - novos súditos cristãos do império português. 2000. Tese (Doutorado em Ciências Sociais) - Universidade Estadual de Campinas, Campinas. 2000.

CERTEAU, Michel de. A invenção do cotidiano: artes de fazer. 17. ed. Trad. Ephraim Ferreira Alves. Petrópolis: Vozes, 2017.v. 1.

COELHO, Mauro Cezar. Do Sertão para o Mar. Um estudo sobre a experiência portuguesa na América, a partir da colônia: o caso do Diretório dos Índios (1757-1798). 2005. Tesé (Doutorado em História Social) - Universidade.de São Paulo, São Paulo. 2005.

DIRECTORIO que se deve observar nas Povoaçoens dos Indios do Pará, e Maranhaõ em quanto Sua Majestade naõ mandar o contrario [3 maio 1757]. In: MOREIRA NETO, Carlos de Araújo. Indios da Amazônia: de maioria a minoria (1750-1850). Petrópólis: Vozes, 1988. p. 165-206.

ELIAS, Norbert. O processo civilizador. Formação do estado e civilização. Trad. Ruy Jungmann. Rio de Janeiro: Jorge Zahar, 1993. v. 2.

O processo civilizador. Uma história dos costumes. Trad. Ruy Jungmann. 2. ed. Rio de Janeiro: Jorge Zahar, 1994.v. 7.

FOUCAULT, Michel. Vigiar e punir: nascimento da prisão. Trad. Raquel Ramalhete. Petrópolis: Vozes, 1987. 
CINZBURG, Carlo, Sinais: raízes de um paradigma indiciário. In: Mitos, emblemas, sinais: morfologia e história. Trad. Federico Carotti.São Paulo: Companhia das Letras, 1989: p. 143-179.

MONTEIRO, John Manuel. Tupis, Tapuias e Historiadores: estudos de história indígena e do indigenismo. 2001. Tese (Livre-Docência) - Universidade Estadual de Campinas, Campinas. 2001

MOREIRA NETO, Carlos Araújo. Índios da Amazônia: de maioria a minoria (1750-1850). Petrópolis: Vozes, 1988

NORONHA, José Monteiro de. Roteiro da Viagem da Cidade do Pará até as Últimas Colônias do Sertão da Província [1768]. Introdução e notas de Antonio Porro. São Paulo: Edusp, 2006.

OLIVEIRA, João Pacheco de. Uma etnologia dos "índios misturados"? Situação colonial, territorialização e fluxos culturais. In: (Org.). A viagem de volta: etnicidade, política e reelaboração cultural no Nordeste indígena. 2. ed. Rio de Janeiro: Contra Capa; LACED, 2004. p. 13-42.

OLIVEIRA, João Pacheco de; FREIRE, Carlos Augusto da Rocha. A presenç̧a indígena na formação do Brasil. Brasília: MEC/SECAD; LACED/Museu Nacional, 2006.

PACHECO, Agenor Sarraf. Encantarias Afroindígenas na Amazônia Marajoara: Narrativas, Praticas de Cura e (In)tolerâncias Religiosas. Horizonte, Belo Horizonte, v. 8, n.17, p. 88-108, 2010. ISSN $2775-5841$.

PERRONE-MOISÉS, Beatriz. Índios livres e índios escravos: os princípios da legislação indigenista do período colonial (séculos XVI a XVIII). In: CUNHA, Manuela Carneiro da (Org.). História dos índios no Brasil. São Paulo: Companhia das Letras; Secretaria Municipal de Cultura; FAPESP, 1992. p. $115-132$.

POMPA, Cristina. Identidades negociadas no sertão do nordeste. Séculos XVIII e XIX. In: ENCONTRO ANUAL DAASSOCIAÇÃO NACIONAL DE PÓS-GRADUAÇÃO E PESQUISA EM CIÊNCIAS SOCIAIS, 32., 2008, Caxambu (MG). Anais... [S.I.]: Anpocs, 2008. p. 7-19. ISSN 2177-3092. Disponível em: $<$ http://www.anpocs.com/index.php/papers-32-encontro/gt-27/gt20-23/2492-cristinapompa-identidades/file>. Acesso em: mar. 2017.

PORRO, Antonio. História indígena do Alto e Médio Amazonas: séculos XVI a XVIII. In: CUNHA, Manuela Carneiro da (Org.). História dos índios no Brasil. São Paulo: Companhia das Letras; Secretaria Municipal de Cultura; Fapesp, 1992. p. 175-196.

USP, 2007

Dicionário etno-histórico da Amazônia colonial. São Paulo: Instituto de Estudos Brasileiros/

PRIORE, Mary del. Histórias da gente brasileira. Colônia. São Paulo: LeYa, 2016. v. 1.

ROCHA, Rafael Ale. Os oficiais índios na Amazônia pombalina: sociedade, hierarquia e resistência (1751-1798). 2009. Dissertação (Mestrado em História) - Universidade Federal Fluminense, Rio de Janeiro. 2009. 
SAMPAIO, Patrícia Maria Melo. Espelhos Partidos: etnia, legislação e desigualdade na Colônia. Manaus: UFAM, 2011.

SILVA, Kalina Vanderlei; SILVA, Maciel Henrique. Dicionário de conceitos históricos. 2. ed 2. reimpr. São Paulo: Contexto, 2009.

SOUZA JUNIOR, José Alves de. Tramas do cotidiano: religião, política, guerra e negócios no Grão-Pará do setecentos. Um estudo sobre a Cómpanhia de Jesus e a política pombalina. 2009. Tese (Doutorado em História Social) - Pontifícia Universidade Católica de São Paulo, São Paulo. 2009

THOMAS, Kheith. O predomínio humano. In: O homem e mundo natural: mudanças de atitude em relação às plantas e aos animais (1500-1800). Trad. João Roberto Martins Filho. São Paulo: Companhia das Letras, 1988. p. 21-60.

VEYNE, Paul: Como se escreve a história. Foucault revoluciona a história. 4. ed. Trad. Alda Baltar e Maria Auxiliadora Kneipp. Brasília: UnB, 2008. 
